\title{
Isolation and purification of functional total RNA from different organs of cacao tree during its interaction with the pathogen Crinipellis perniciosa
}

\author{
Abelmon da Silva Gesteira ${ }^{1}$, Fabienne Micheli ${ }^{1,2}$, Cláudia Fortes Ferreira ${ }^{3}$, \\ and Júlio Cézar de Mattos Cascardo ${ }^{1}$ \\ ${ }^{1}$ DCB/UESC, Bahia, Brazil, ${ }^{2}$ CIRAD-CP, Montpellier, France, and ${ }^{3}$ EMBRAPA, \\ Cruz das Almas-BA, Brazil
}

BioTechniques 35:494-500 (September 2003)

Witches' broom disease, caused by Crinipellis perniciosa, is one of the major fungal diseases causing severe losses to cacao tree (Theobroma cacao L.) plantations in South America. One of the challenges associated with the understanding of the cacao and Crinipellis interaction in genomic studies is the isolation of intact nucleic acids. In this report, we describe a new, successful, and reliable procedure for the isolation of RNA from tissues of cacao tree, both infected and uninfected by Crinipellis. This protocol overcomes the problems associated with the very high amount of polyphenols and polysaccharides present in cacao organs that are not easily removed by conventional extraction procedures. The protocol requires few reagents, uses ultracentrifugation and inexpensive consumables, and can be easily applied in any laboratory. This method produced high-quality RNA that was suitable for subsequent purposes, such as reverse transcription PCR and cDNA library construction. We also report the first evidence of RNA isolation from cacao organs infected by C. perniciosa such as meristems and fruits.

\section{INTRODUCTION}

Since 1989, witches' broom disease, caused by the pathogenic fungus Crinipellis perniciosa, has spread throughout Brazil, destroying cacao tree (Theobroma cacao L.) plantations and leading to important economical and social changes in affected areas $(1,2)$. For cacao and many pathogenic systems in plants, the study of gene interaction is a suitable approach to discover plant defense mechanisms. The aim of the research developed in the laboratory is to acquire a thorough understanding of the interaction between the cacao tree and Crinipellis, based on functional genomic studies. One of the challenges associated with conducting research is the isolation of intact nucleic acids, especially RNA. This is particularly difficult due to the high content of polyphenols and polysaccharides that are present in the different cacao tissues and co-precipitate with nucleic acids upon isolation $(3,4)$. Moreover, the amount of polysaccha- rides is higher in some organs such as meristems or fruits, which are, unfortunately, the organs infected by Crinipellis, than in leaves or seeds.

Several protocols exist for isolating RNA from recalcitrant plants (5-10), and only few recent studies examine the isolation of cacao RNA (11-13). However, these methods either use a $\mathrm{CsCl}$ gradient and ultracentrifugation or result in a low RNA yield.

The isolation of RNA from cacao was first attempted in our laboratory using classical methods of extraction and several commercially available kits, without success. Here we describe a successful and reliable procedure for the isolation of RNA from cacao organs infected and uninfected by Crinipellis. This new protocol overcomes the problems associated with polyphenol and polysaccharide contaminations. Moreover, it uses a inexpensive method without ultracentrifugation that can be easily applied in any laboratory. The quality of the isolated RNA obtained was consistently high, as confirmed by 
spectrophotometric analysis and by its separation on agarose gel, and could be used for subsequent applications such as reverse transcription PCR (RT-PCR) and cDNA library construction.

\section{MATERIALS AND METHODS}

\section{Plant Material}

The plant material (leaves, meristems, and fruits) was obtained from the cacao tree ( $T$. cacao L.) variety Catongo, which grows in the field of the Universidade Estadual de Santa Cruz, Bahia, Brazil.

\section{RNA Extraction from Cacao Tissues with a New Protocol Using Tertiary- Butanol}

All solutions were treated with $0.1 \%$ (v/v) of diethylpyrocarbonate (DEPC), except that the Tris buffer was made with DEPC-treated water. Mortars,

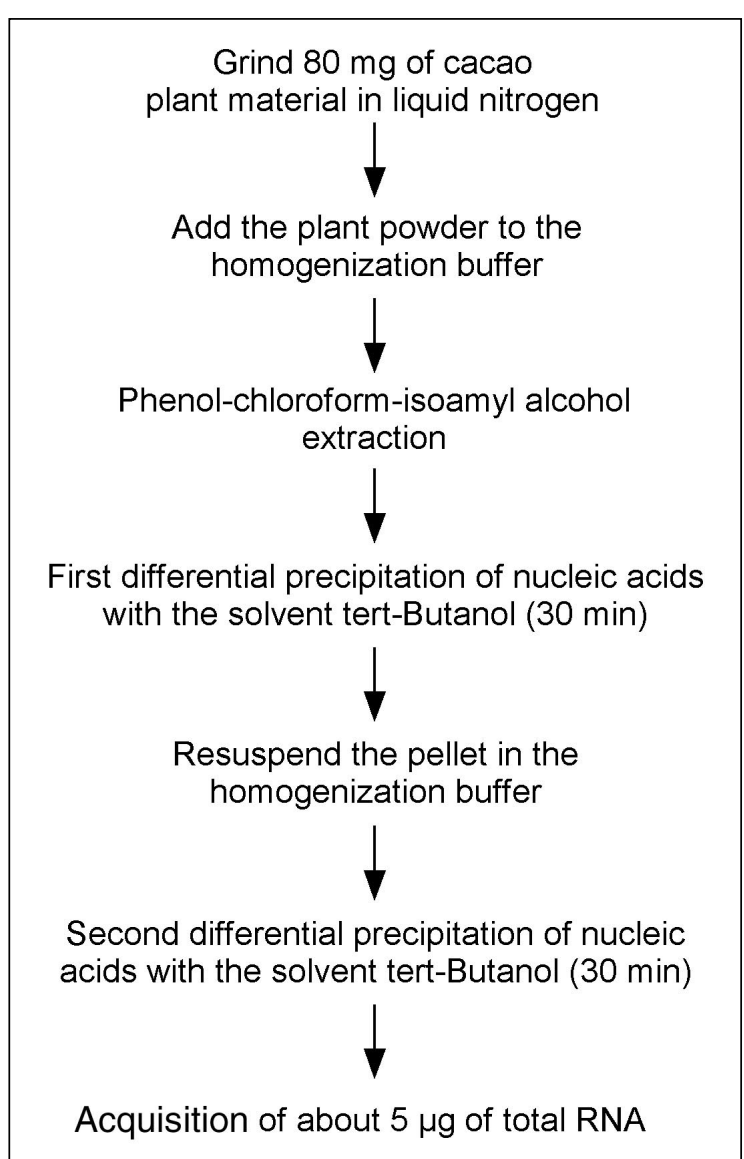

Figure 1. Purification steps for the isolation of total RNA from cacao tissue. pestles, and spatulas were soaked overnight in a $0.1 \%(\mathrm{v} / \mathrm{v})$ solution of DEPC and then autoclaved before use. Eighty milligrams of the cacao tissue were homogenized to a fine powder using liquid nitrogen and transferred into a $2-\mu \mathrm{L}$ sterile microcentrifuge tube (Scientific Specialties, Lodi, CA, USA). One milliliter of homogenization buffer $(0.2 \mathrm{M}$ boric acid, $10 \mathrm{mM}$ EDTA, $\mathrm{pH}$ adjusted to 7.6 with Tris), $20 \mu \mathrm{L} 25 \%$ sodium dodecyl sulfate (SDS), and $20 \mu \mathrm{L} 14.3$ M $\beta$-mercaptoethanol were added. The mixture was shaken for $10 \mathrm{~min}$ and then centrifuged at $15,000 \times g$ at room temperature for $10 \mathrm{~min}$. The upper aqueous phase containing nucleic acids and a great amount of polysaccharides was carefully transferred to a new tube, extracted with $1 \mathrm{~mL}$ phenol/ chloroform/isoamyl alcohol (25:24: $1 ; \mathrm{v} / \mathrm{v} / \mathrm{v})$, shaken for $10 \mathrm{~min}$, and then centrifuged at $15,000 \times g$ at room temperature for $10 \mathrm{~min}$. Finally, the upper aqueous phase was extracted with 1 $\mathrm{mL}$ chloroform/isoamyl alcohol (24: $1 ; \mathrm{v} / \mathrm{v})$. The separation of the nucleic acids from the polysaccharides was made by the addition of $70 \mu \mathrm{L} 3$ M sodium acetate, $\mathrm{pH} 4.5$, and $308 \mu \mathrm{L}$ tertiary (tert)butanol (0.4 volumes) to the upper aqueous phase $(700 \mu \mathrm{L})$. The tubes were kept on ice for $30 \mathrm{~min}$ while shaking in a Model MA140 shaker (Marconi, Piracicaba-SP, Brazil) and then centrifuged in a Model 5417R centrifuge (Eppendorf, Westbury,
NY, USA) at $15,000 \times g$ at $4^{\circ} \mathrm{C}$ for 10 min. The supernatant was carefully recovered, mixed with $462 \mu \mathrm{L}$ tert-butanol, then kept on ice for $30 \mathrm{~min}$. After $20 \mathrm{~min}$ of centrifugation at $15,000 \times g$ $\left(4^{\circ} \mathrm{C}\right)$, the pellet was washed with $70 \%$ ethyl alcohol and resuspended in 900 $\mu \mathrm{L}$ homogenization buffer. The second differential precipitation of polysaccharides was performed by the addition of $90 \mu \mathrm{L} 3 \mathrm{M}$ sodium acetate, $\mathrm{pH} 4.5$, and $396 \mu \mathrm{L}$ tert-butanol ( 0.4 volumes). The tubes were kept on ice for $30 \mathrm{~min}$ while shaking and then centrifuged at $15,000 \times g$ at $4^{\circ} \mathrm{C}$ for $10 \mathrm{~min}$. The supernatant was carefully recovered, mixed with $594 \mu \mathrm{L}$ tert-butanol, and then kept on ice for $30 \mathrm{~min}$. After 20 min of centrifugation at $15,000 \times g$ $\left(4^{\circ} \mathrm{C}\right)$, the pellet was washed with $70 \%$ ethyl alcohol and resuspended in DEPC-treated water (Figure 1). During the first differential precipitation of the nucleic acids, we tested several concentrations of tert-butanol $(0.4,0.5$, and 0.6 volumes).

The samples were treated with RNase-free DNase I (amplification grade; Invitrogen, Carlsbad, CA, USA) according to the manufacturer's instructions. RNA was then extracted further with the phenol/chloroform/isoamyl alcohol step as described earlier and precipitated with one-tenth volume of 3 $\mathrm{M}$ sodium acetate, $\mathrm{pH} 4.5$, and 2.5 volumes of $100 \%$ ethyl alcohol. The purity and concentration of the purified RNA were determined spectrophotometrically at $260 \mathrm{~nm}\left(\right.$ Cary $^{\circledR} 100 \mathrm{UV}$-Visible Spectrophotometer; Varian, Palo Alto, CA, USA). The RNA was electrophoresed on $1 \%$ agarose gel that had been 
DEPC-treated and stained with ethidium bromide to confirm RNA integrity.

\section{Reverse Transcription PCR}

Single-stranded cDNA was synthesized from $1 \mu \mathrm{g}$ total RNA of infected cacao meristem using the SUPERSCRIPT $^{\text {TM }}$ II RNase H-Reverse Transcriptase kit and oligo(dT), as described by the manufacturer (Invitrogen). The cDNA was used for the PCR amplification of the Crinipellis hydrophobin and actin sequences (14) under the following conditions: $1 \mu \mathrm{L}$ cDNA was mixed with $1.2 \mathrm{mM} \mathrm{MgCl} 2$, $1 \times$ Tris, 0.6 mM dNTPs, 1 U Taq DNA polymerase (Invitrogen), and $0.2 \mu \mathrm{M}$ forward and reverse primers. The specific primers were Pr2Forward (5'-GCGGATCCCACACCGACTCGTCG-3') and Pr2Reverse (5'-AAGGATCCACAGGAAAGTTCTTA-3') for the hydrophobin and ActinCP-F (5'-CCACAATGGAGGACGAAGTCG-3') and ActinCP-R (5'-CCCGACATAGGAGTCCTTCTG-3') for the actin. The following PCR programs were used: $94^{\circ} \mathrm{C}$ for $5 \mathrm{~min}, 35$ cycles of $94^{\circ} \mathrm{C}$ for $30 \mathrm{~s}$, $55^{\circ}$ (for the hydrophobin sequence) or $67^{\circ} \mathrm{C}$ (for the actin sequence) for $45 \mathrm{~s}$, $72^{\circ} \mathrm{C}$ for $1 \mathrm{~min}$, and $72^{\circ} \mathrm{C}$ for $7 \mathrm{~min}$. The same conditions were applied to amplify the actin gene, which differs from the cDNA by the presence of a 208-bp intron, from the Crinipellis genomic DNA that was isolated as previously described (15). The actin gene-specific primers were defined according to a previous Basic Local Alignment Search Tool (BLAST) analysis that revealed that the amplified region did not have any homology with plant actin genes (data not shown). This precaution was taken to avoid crossamplifications of a possible cacao actin gene. PCR and RT-PCR products were separated on a $1 \%$ agarose gel and visualized by ethidium bromide staining.

\section{RESULTS AND DISCUSSION}

\section{Extraction of RNA from Cacao Tissues}

Cacao RNA extraction was successfully carried out using the new tert-butanol method described in this report. The homogenization buffer (containing boric acid) associated with SDS and $\beta$-mercaptoethanol facilitates the recovery of RNA by enhancing the dissolution of the cell wall and by the denaturation of proteins and prohibits the endogenous phenolic compound oxidation and the binding of phenolics to RNA (16). Moreover, the polyphenol oxidase activity was reduced due to the alkaline $\mathrm{pH}$ of the homogenization buffer. This method takes advantage of the difference in the solubility of polyphenols, polysaccharides, and nucleic acids in the tert-butanol solvent. To improve the polysaccharide separation from the nucleic acids during the first differential precipitation (Figure 1), several amounts of tert-butanol were tested. We obtained the best yield of RNA with the lower concentration of tert-butanol (Figure 2). On the other hand, the use of a small amount of tertbutanol in a high volume of homogenization buffer $(900 \mu \mathrm{L})$, as used in the second differential precipitation step, greatly improved the separation of the polysaccharides from the cacao RNA and prevented their inhibitory effects on enzymatic reactions.

Nondegraded total RNA was obtained using the newly developed method. Intact bands of $28 \mathrm{~S}, 18 \mathrm{~S}$, and $5 \mathrm{~S}$ rRNAs were detected on DEPCtreated $1 \%$ agarose gel in all RNA fractions from the different organs of cacao infected by Crinipellis, such as meristem and fruit (Figure 3, B and E), or uninfected, such as leaves and fruit (Figure 3, A and D). Contrary to seeds, which are usually used in molecular biology studies of cacao (11-13),

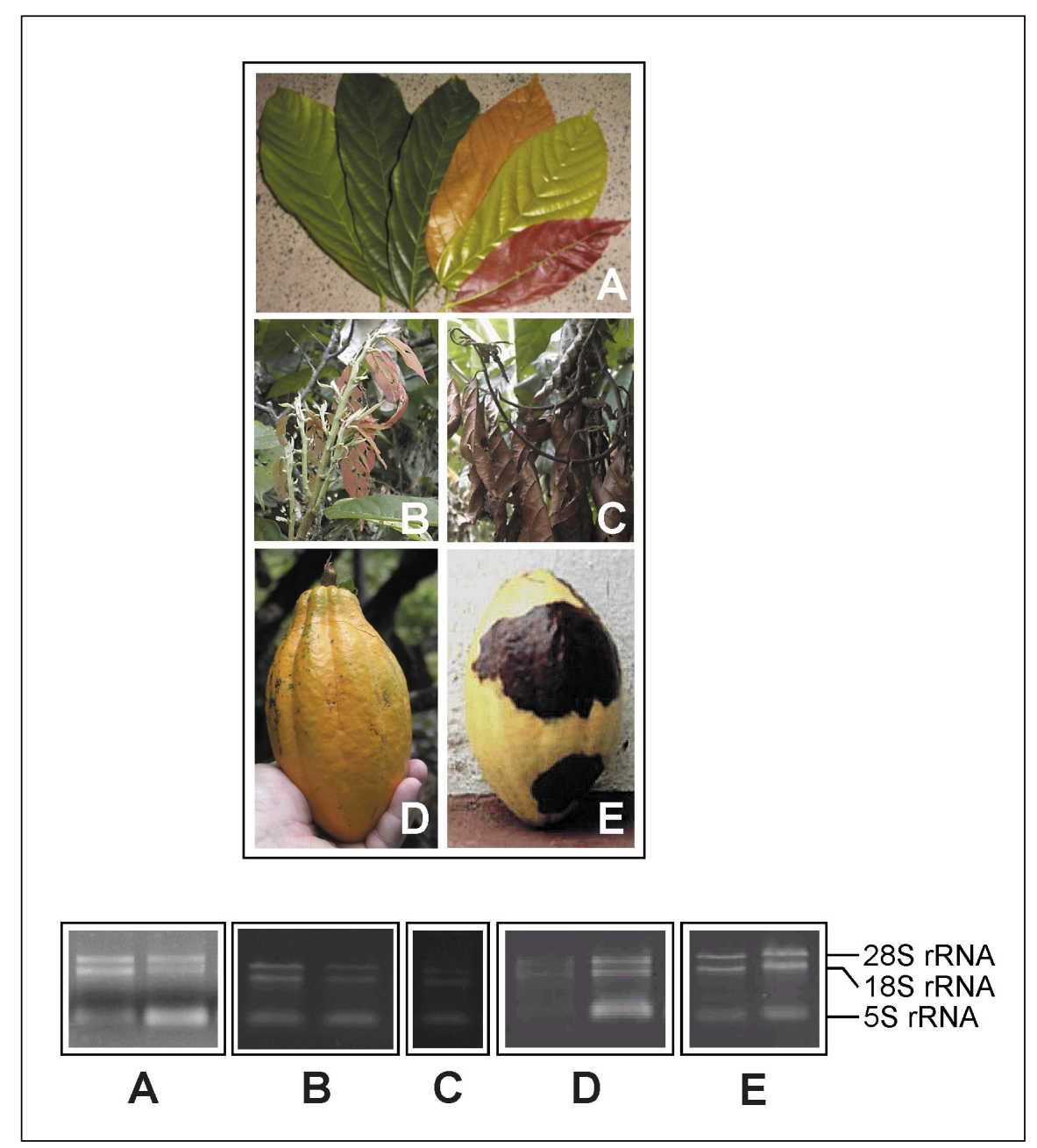

Figure 3. RNA pattern obtained using the tertiary-butanol method. RNA was extracted from the following organs: (A) leaves, (B) meristem inoculated by Crinipellis, (C) dry broom, (D) uninfected fruit, and (E) fruit infected by Crinipellis. 
these organs, particularly meristem and fruit, contain high amounts of polysaccharides that could not be removed by conventional extraction procedures. The tert-butanol method also enabled the RNA extraction from an almost dry broom that contained only few intact cells (Figure 3C).

The quality of the RNA obtained from cacao tissues was good as assayed by the $\mathrm{A}_{260} / \mathrm{A}_{280}$ ratio, which is approximately 1.85 . Further assessment of the RNA quality was obtained by the visualization of the major ribosomal

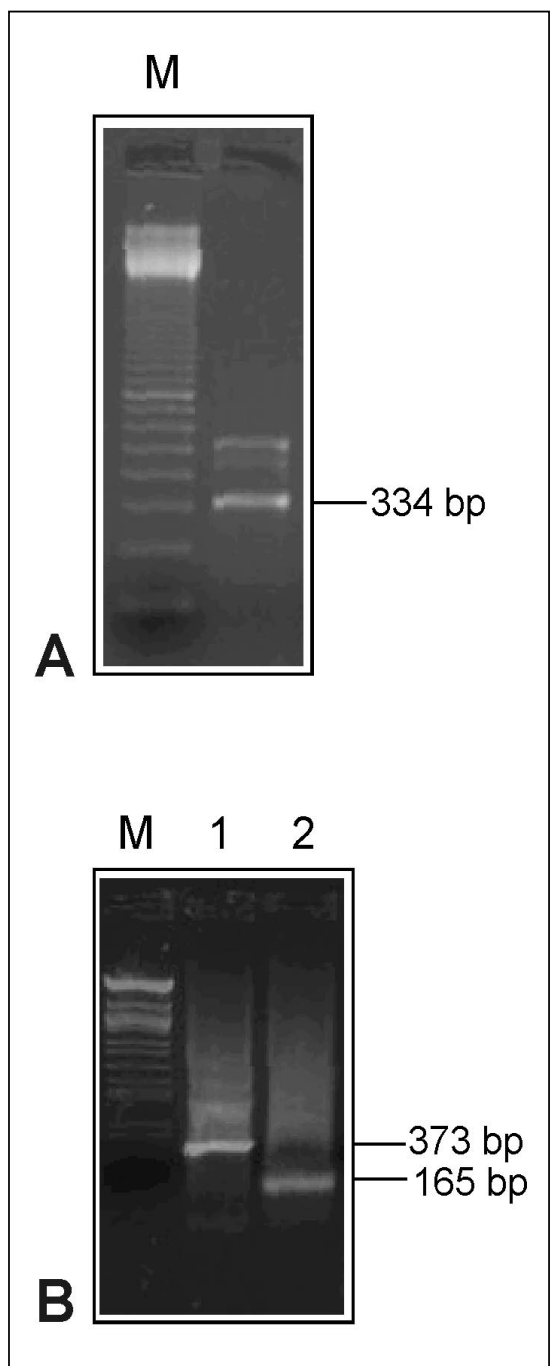

Figure 4. Reverse transcription PCR product obtained from the total RNA of the meristem of cacao infected by Crinipellis. (A) PCR amplification of the hydrophobin cDNA. M, 100-bp DNA ladder (Invitrogen). (B) PCR amplification of the actin sequence from Crinipellis genomic DNA (line 1) and from cDNA (line 2). M, size marker $\lambda$ digested by EcoRI, HindIII, and BamHI.
RNAs, following their separation on DEPC-treated $1 \%$ agarose gel. No degradation of the RNA was observed on these gels. Total RNA was obtained with a very good yield; approximately $5 \mu \mathrm{g}$ for $80 \mathrm{mg}$ of ground plant material were used initially (i.e., approximately 60 ng total RNA/mg of cacao tissue). This protocol could be adapted for RNA extraction from greater amounts of cacao plant material, requires few reagents, uses cheaper consumables, and could be easily applied in any laboratory. Furthermore, the study of the kinetics of the interaction between cacao and $\mathrm{Cr}$ nipellis (to 70 days to obtain dry broom) demands a fast isolation procedure that can be carried out in microcentrifuge tubes to prepare and analyze RNA from many samples in parallel. 


\section{Reverse Transcription PCR}

To determine whether the RNA was suitable for purposes such as cDNA library construction and gene expression, it was used as a template for RTPCR. The total RNA of the infected cacao meristem was used, RT-PCR was performed using hydrophobin and actin primers, and the products were separated on $1 \%$ agarose gels. Major PCR products of 334 and 165 $\mathrm{bp}$, corresponding to the amplification of hydrophobin (Figure 4A) and actin (Figure 4B, line 2) cDNA, respectively, were obtained. While Figure 4A shows that supplementary bands were observed due to the existence of a hydrophobin gene family in fungi (17) and, consequently, to an unspecific amplification of other members of this family, the RT-PCR results were in agreement with the amplification band size predicted by previous BLAST analyses. Figure 4B shows that the comparison between the size of the actin amplification product from genomic DNA (373 bp, line 1) and cDNA (165 bp, line 2) shows that the RNA extraction is free of DNA contamination. These results confirmed the possible use of the extracted RNA for further experiments, without any inhibition of enzymatic reactions, as reported in other RNA extraction protocols (18).

Here we report the first evidence of RNA isolation from cacao organs infected by $C$. perniciosa. These results allow new perspectives regarding the understanding in genomic studies of the cellular mechanisms of the infection of the cacao tree by different devastating pathogens such as Crinipellis or Phytophthora spp.

\section{ACKNOWLEDGMENTS}

Dr A.S. Gesteira is supported by the Research Support Foundation of the Bahia State (PRODOC/FAPESB No. 76/2002). We thank L.L. Fialho (University of Viçosa, MG, Brasil) for helpful advice and A.C. Silva and S.C. Santos for technical assistance. This project is supported by FAPESB No. 89-155/00 and BNB No. 96 (J.C.M.C.) research grants.

\section{REFERENCES}

1.Pereira, J.L., A. Ram, J.M. Figueiredo, and L.C. Almeida. 1989. Primeira ocorrência de vassoura-de-bruxa na principal região produtora de cacau do Brasil. Revista Agrotrópica 1:79-81.

2.Dos Santos Filho, L.P., E.S. Freire, and I.M. Carzola. 1998. Estimation of cacao production losses caused by witches' broom (Crinipellis perniciosa (Stahel) Singer) in Bahia. Agrotropica 10:127-130.

3.Figueira, A. 1994. Partial characterization of cacao pod and stem gums. Carbohydr. Polym. 24:133-138.

4.Redgwell, R.J. and C.E. Hansen. 2000. Isolation and characterisation of cell wall polysaccharides from cocoa (Theobroma cacao L.) beans. Planta 210:823-830.

5.Schneiderbauer, A., H. Sandermann Jr., and D. Ernst. 1991. Isolation of functional RNA from plant tissues rich in phenolic compounds. Anal. Biochem. 197:91-95.

6.Schultz, D.J., R. Craig, D.L. Cox-Foster, R.O. Mumma, and J.I. Medford. 1994. RNA isolation from recalcitrant plant tissue. Plant Mol. Biol. Rep. 12:310-316.

7.Burgos, R.C., V.L. Chiang, X.H. Zhang, E.R. Campbell, G.K. Podila, and W.H. Campbell. 1995. RNA isolation from plant tissues recalcitrant to extraction in guanidine. BioTechniques 19:734-737.

8.Chi-Manzanero, B., M.L. Robert, and R.
Rivera-Madrid. 2000. Extraction of total RNA from a high pigment content plant Marigold (Tagetes erecta). Mol. Biotechnol. 16:17-21

9.Suzuki, Y., A. Makino, and T. Mae. 2001. An efficient method for extraction of RNA from rice leaves at different ages using benzyl chloride. J. Exp. Bot. 52:1575-1579.

10.Wang, S.X., W. Hunter, and H. Plant. 2000 Isolation and purification of functional total RNA from woody branches and needles of Sitka and White Spuce. BioTechniques 28: 292-296.

11.Kochhar, S., K. Gartenmann, M. Guilloteau, and J. McCarthy. 2001. Isolation and characterization of $2 \mathrm{~S}$ cocoa seed albumin storage polypeptide and the corresponding cDNA. J. Agric. Food Chem. 49:4470-4477.

12.Jones, P.G., D. Allaway, D.M. Gilmour, C. Harris, D. Rankin, E.R. Retzel, and C.A. Jones. 2002. Gene discovery and microarray analysis of cacao (Theobroma cacao L.) varieties. Planta 216:255-264.

13.Laloi, M., J. McCarthy, O. Morandi, C. Gysler, and P. Bucheli. 2002. Molecular and biochemical characterisation of two aspartic proteinases TcAP1 and TcAP2 from Theobroma cacao seeds. Planta 215:754-762.

14.Santos, S.C. and J.C.M. Cascardo. 2002. Caracterização de hidrofobinas do fungo Crinipellis perniciosa, causador da doença Vassoura-de-Bruxa no cacau, p. 169-171. In 8 Seminário de iniciação científica na UESC, Livro de Resumos. EDITUS, Ilhéus, Brazil.

15.Andebrhan, T., A. Figueira, M.M. Yamada, J. Cascardo, and D.B. Furtek. 1999. Molecular fingerprinting suggests two primary outbreaks of witches' broom disease (Crinipellis perniciosa) of Theobroma cacao in Bahia, Brazil. Eur. J. Plant Pathol. 105:167-175.

16.Wan, C.Y. and T.A. Wilkins. 1994. A modified hot borate method significantly enhances the yield of high-quality RNA from cotton (Gossypium hirsutum L.). Anal. Biochem. 223:7-12.

17.Kershaw, M.J. and N.J. Talbot. 1998 Hydrophobins and repellents: proteins with fundamental roles in fungal morphogenesis. Fungal Genet. Biol. 23:18-33.

18.Staub, U., H. Polivka, and H.J. Gross. 1995. Two rapid microscale procedures for isolation of total RNA from leaves rich in polyphenols and polysaccharides: application for sensitive detection of grapevine viroids. J. Virol. Methods 52:209-218.

Received 16 April 2003; accepted 27 May 2003.

Address correspondence to Fabienne Micheli, UESC/DCB, Laboratório de Gênomica e Expessão Gênica, Rodoviaria Ilhéus-Itabuna km 16, Ilhéus-BA, Brasil, 45650-000.e-mail: micheli@cirad.fr 